\title{
THE USE OF CODE SWITCHING BY LECTURERS IN TEACHING PROCESS AT UNIVERSITY OF MUHAMMADIYAH SORONG
}

\author{
Hasanudin \\ Department of English Education, Faculty of Teacher Training and Education, University \\ of Muhammadiyah Sorong \\ e-mail: hasanuddin.ums@gmail.com
}

\begin{abstract}
(The Use of Code Switching by Lecturers in Teaching Process at University of Muhammadiyah Sorong| Code Switching is a process of language which intentionally or unintentionally people talk affected by situation and topic with inserted other language when speaking their language. There were three main problems of this research (1). How often do the lecturers make code switching in the learning process? (2). What are types of code switching that used by lecturers in the learning process? (3). What are the factors cause the lecturers used code switching in the learning process? The method of this research was descriptive gualitative. To gain the data, this research used a recording device, field notes, and a guestionnaire. After analyzing the data, it concluded that all of the lecturers used code switching in the teaching learning process more than 244 occurrences of code switching and more $86.67 Y^{\prime \prime} 6$ responded agree that they often did code switching when teaching. They did code switching based on their material and orally. The writer also found the English codes with added Indonesian prefix and suffix likes dismoothkan, diprint out, utilizingnya, etc. Then, freguently of the codes were Fisheries Faculty 111 of occurrences (45.49"o) Engineering Faculty 59 (24.180), Law of Faculty 25 (10.25Y9), Sociology Faculty and Administrative Science 25 (10.25Y6) and the remaining 24 occurrences (9.84"6) are Agriculture Faculty. About 54 statements that shown as situational code switching and nine statements were metaphorical code switching. And ten out 15 factors that the lecturers agree from statements contained in the guestionnaire and five factors were disagreed.
\end{abstract}

Keyword: Code Switching, Lecturers, Teaching Process

\section{BACKGROUND}

A communicative system is one feature that makes individual or member of society differ from others. The system meant here is known as language. Recently, language has an 
important role in human life. It is not only used in the daily activity like at home but also in the workplaces and education scope. People certainly agree between language and human likes two-sided coin that cannot be separated from human life. In bilingual and multilingual people including people of Indonesia in general and especially for Papua People is commonplace to have two languages or more. For instance, their mother tongue is Indonesian (L1) and the second language (L2) is English and when they are having a conversation, they usually switching the words of the language, from LI to L2 and vice versa. This case is or during the same conversation. Code-switching can be intra-sentential or inter-sentential. In intra- sentential code-switching, speakers alternate from one language to the other one within a sentence, whereas in inter sentential code-switching, conversational participants code-switch between sentences (Myers, 1990).

This phenomenon also happens in the learning process from elementary school up to university. It would happen because the speakers know more than one language. For examples, in a daily conversation in the classroom that code switching happens and probably we all ever felt it, when a lecturer explains about the material after he talked one page and he said "next, buka halaman 12"(next, open page 12). Other example is when the teacher made mistake and he said "sorry... Sorry... yang bagian ini saya salah" (sorry..sorry.. I made mistake in this part). Apparently, these sentences show code switching happen between English and Indonesian.

Code switching (CS) occurs not only in English Education Department of Teacher Training and Education Faculty of Sorong Muhammadiyah University but also in other faculty likes Engineering Faculty, Faculty of Law and Sociology Faculty and Administrative Science, etc. The writer believes that could be interested to discuss and to find out this phenomenon in other faculty.

\section{Problem Statement}

1. How often do the lecturers make code switching in the learning process? 
2. What are the types of code switching that used by lecturers in the learning process?

3. What are the factors cause the lecturers used code switching in the learning process?

Significance of the Research

An analysis on code switching as one phenomenon in sociolinguistics, the result of this study expected to give some contribution on both, theoretical and practical significances. Theoretical aspects could be useful for developing knowledge and adding insight for people so that can be applied in their daily activity and It is to prove the existed theory on sociolinguistics that is as one phenomenon in social context happens beside to support the study of sociolinguistics especially in code switching. Practical aspects are by this research the writer will get the description of code switching that used by lecturers and hopefully it would be useful for the readers and especially for people who live in the bilingual or multilingual community. In which, it can make a variety in communication and make easy communication in their society.

Review of Related Literature

Code Switching (CS) has been researched by many scholars in many countries, not only Indonesia but also other countries in the world. One of the researchers is Apriana (2007), found the factor that caused the code switching was the mother tongue of the lecturers are still Indonesian, so the emergence of some of the particles in the Indonesian language sometimes difficult to avoid. Gulzar (2010) found that, although preliminary in nature, attempted to highlight and explain some of the functions of code-switching in the foreign language classroom. In short, this paper attempted to make a better understand the trends of code- switching in Pakistani EFL classrooms. Ahmad (2009) found that, codeswitching in classroom instructions for low English proficient learner study investigated 257 low English proficient learners attending Communication one proficiency course in a public university in Malaysia. Sinulingga (2009) found that, thirteen code switching cases consist of: two situational code switching cases and eleven metaphorical code switching, 
fourteen code mixing cases. Karimah (2011) found that the form of code switching is external code switching and the function of code switching are informational, directive, and expressive, the forms of code mixing are: word, phrase, hybrid, and clause and the function of and code mixing are: informational, and directive.

Some Pertinent Ideas 1. Sociolinguistics

According to Fasold (1984: 1) sociolinguistics of society is about the social importance of language to groups of people, from small socio-cultural groups of a few hundred people to entire nations. Wardaugh (2006: 13) in his book "An Introduction to Sociolinguistics" that statement he said sociolinguistics is concerned with investigating the relationships between language and society with the goal being a better understanding of the structure of language and of how languages function in communication. Meyerhoff (2006: 1) Sociolinguistics is a very broad field, and it can be used to describe many different ways of studying a language. This is what we mean when we say that sociolinguists are interested in both "social" guestions and "linguistic" guestions. Inevitably, some sociolinguistics research has more to say about social issues, and some sociolinguistic research has more to say about linguistic matters. But what makes someone's work distinctively sociolinguistic will be the fact that, regardless of its emphasis, it has something to say about both linguistic structure and social structure (Meyerhoff, 2006: 3)

From some theories, it can conclude that sociolinguistics is the study of language existed in the community in social groups, the speakers used that language different usage according to age, gender, and the context and sometimes they used of language that occurs in society arise languages new and funny.

\section{Bilingualisms}

Discussing bilingualism, there are some theories that the writer wants to expose. Potowski and Rothman (2011: 3) give the explanation about bilingualism, if in many 
societies where English is the dominant language - including Australia, Canada, New Zealand, the U.K., and the U.S. - we notice a different dominant pattern: one of monolingualism in English. Broadly defined, bilingualism refers to knowledge and command of two or more languages, albeit to different degrees. Two common parameters that distinguish bilingualism are the age of acguisition (early in childhood versus late after puberty), and order or seguence of acguisition in childhood (two languages being acguired simultaneously versus one language being acguired successively, after the other). Even though second language acguisition is treated as a separate field of study, it is a particular case of bilingualism: early (with children) or late (with post-pubescent and adults) L2 acguisition (Montrul, 2008: 17).

\section{Code Switching (CS)}

Wardaugh (2006: 101) said that Code Switching (also called code mixing) could occur in a conversation between speakers' turns or within a single speaker's turn. In the latter case, it can happen between sentences (inter-sententially) or commonly known as Code Switching. Wardaugh (2010) defined it as the alternate use of two or more linguistic varieties within the same utterance within a single sentence (intra-sententially). Moreover, As Gal 1988: 247 (cited in Wardaugh, 2006: 101) says, that code switching is a conversational strategy used to establish, cross or destroy group boundaries, to create, evoke or change interpersonal relations with their rights and obligations. We will now look more closely at this phenomenon. Meyerhoff (2006: 115-116) says that People who speak more than one language, or who have command over more than one variety of any language, are generally very sensitive to the differences in the vitality of the languages. Moreover, they use and they are egually aware that in some contexts one variety will serve their needs better than another.

\section{Types of Code Switching}

In the book of Wardaugh (2006: 104) "An Introduction to Sociolinguistics" he describes two kinds of code switching: 
Situational code-switching occurs when the language used change according to the situations in which the conversant find themselves: they speak one language in one situation and another in a different one. No topic change is involved.

Metaphorical code-switching, when a change of topic reguires a change in the language used. He states the interesting point here is that some topics may be discussed in either code, the choice of code adds a distinct flavor to what is said about the topic.

4. Factors of the Use of Code Switching

According to Hoffman, 1991: 116 (cited in Cakrawarti: 2011) there are reason for bilingual or multilingual person to switch or mix their languages. They are:

a) Talking about a Particular Topic

b) Guoting Somebody Else

c) Being Emphatic About Something (Express Solidarity)

d) Interjection (Inserting Sentence Fillers or Sentence Connectors)

e) Repetition Used for Clarification - Intention of Clarifying the Speech Content for Interlocutor

f) Expressing Group Identity

Methods

To answer those of the guestions, the writer used percentage to find out the code switching occurrences and the research was held under the descriptive gualitative method in which come along with grounded theory design in accordance with the existence of code switching.

Subject of the Research 
The subject in this research was all of the lecturers at the University of Muhammadiyah Sorong and purposive sampling used to choose all the sampling. The total of the participants were fifteen lecturers, consist of three lecturers from Engineering Faculty, three lecturers from Law of Faculty, three lecturers from Agricultural Faculty, three lecturers from Fisheries Faculty and the last three lecturers from Sociology Science and Administrative Faculty.

\section{Data Analysis}

The goals of this research were based on the problem statements. To answer the first guestion, after collected the data the writer count the percentage. The second guestion on the research problems was analyzed by using grounded theory approach. The last guestion was answered by researcher by using guestionnaire, which contained sixteen items. For tabulated it into scoring classification. In analyzing data, the writer guoted Likert Scale.

\section{Findings and Discussions}

The results showed that all the lecturers used code-switching when they taught in the class even as an instruction language, a joke, contain in

their material or for make students a better understanding.

The freguency of code switching occurrences showed Fisheries Faculty has many attained of code switching occurrences. It revealed more than 111 occurrences (45.49”5) out of 244 occurrences of code switching, 59 occurrences (24.180) are Technigue Faculty, 25 occurrences (10.255) are Law of Faculty, and 25 occurrences (10.25Y6) are Sociology Faculty and Administrative Science. The remaining 24 occurrences (9.84"o) are Agriculture Faculty. (See table 1)

Faculty Name of Me Fisheries 111 45.49 Engineering 59 24.18 Law 25 10.25 Sociology \& Adm. 25 10.25 Agriculture 249.84

Total 244100 Table 1 
The writer also found the majority of them were in Indonesia language with insertion English, both based on the book or substances on Microsoft PowerPoint and orally. In the process of code- switching contained in their book or the materials already substance on Microsoft PowerPoint, such as:

g) AASHTO sendiri kepanjangan dari The American Association of State Highway, ya. Official.

And when they were explain in orally the process of code switching such as:

h) Kita mulai menganalisis dikomputer sehingga bisa diprint out, seperti itu ya.

Additionally, the writer also found English phrases were adding Indonesian suffix and prefix (di-, di- kan, -nya, men-, peng-), such as: basic formnya, engineernya, diincludekan, dismoothkan, etc. 1. How often do the lecturers make code switching?

The data above showed the scale of the lecturers in each faculty used code switching. Beside that result, to measure how often all the lecturers use code switching in teaching learning process. The writer gave an addition statement in the guestionnaire. The statement is "TI often did code switching when teaching". And the result more than $86,67 \mathrm{Y}$ "o responded agree that they often did code switching when teaching, the remaining 13,33Yo responded did not respond.

2. Types of Code Switching Situational code switching

"Fase terakhir itu telofase, fase fisioning, finisiong ya, finis ya. Fase terakhir dimana pada fase ini mulai terlihat adanya sekat yang memisahkan antara sel-sel anak.”

This data belongs to the situational code switching because the respondent in the pronunciation of the phrase. Therefore, there is something wrong and immediately replace with the correct phrase and affirmation with word finis for added asserted part of the sentence is wrong but the word of finisiong that respondent said, it isn't correct and the correct English is finishing. 
Metaphorical code switching

"Karena kita membahas tentang tense-tense jadi semua pakai tensi dibelakang."

The statement can be categorized as metaphorical code switching because it contains the changing topic. She just tries to make ajoke with words that contain in her material, much of the words are tense at the end of the word like absorbance, transmittance, so she takes that part by repeating the word twice and changes the articulate of the word became tensetense which means tense/ emotional.

\section{The Factors Cause of Code Switching}

From the data that the writer has been collected through a guestionnaire given to the lecture after the learning process is completed. The writer found there were ten out of fifteen factors that lecturers

agree the statements contained the factors cause the lecturers used code switching in the learning process. And the remaining 5 factors were classified disagree. (see Table 2)

Percents (Yo) No. Statements

\section{SA A U D SD}

I can't express the eguivalent of 1 (the word that suitable with my| $13.33 \mid 13.33$ | 6.67 | 33.33 | 13.33 language so I did code switching.

The occurrences of code 2 (switching that I used because for| 26-67| 60 | $6.67 \mid 6.670$ compensate the interlocutor.

Changes in circumstances due to a 3 (third person caused me to used $5: 57$ | 40 | 6.67 | $4667 \mid$ 0 code switching.

I do code switching as a language 4 |variation in order to use language | 2333 | 53.33 | 13.33 | 00 more attractive. 
s I will used code switching because I discuss a specific topic.

33.33 | 46.67 | 6.6713 .330

My education is causing 6 freguently of code switching used | 33.33 | 40026.670 in the learning process.

I use code switching in the 7 (learning process to facilitate the $|53.33| 33.33|6.67| 6.670$ material presented.

I want to show my identity that the use of code switching in language that I speak, it's different with the other groups.

$033.33|13.33| 53.330$

T use the code switching just in the formal situation.

6.67402033 .330

I use another language expression 10 Ito convey emotion, surprise andto $5-67 \mid 26.67$ | 13.33 | $46.67 \mid 6.67$ get attention.

I feel comfortable when I using 11 (code switching into other| $6.67|53.33| 20200$ languages.

My environment is greatly affects

, $\mathrm{m} 326.67|606.67| 6.670$ in the use code switching.

12

More use code switching would 13 (be better for students to| 26.67 | 46.67 | 206.670 introduction of foreign language.

14 Foreign terms make me use code $\mid 4667153331000$ switching in the learning process. 
The topic changes resulted I use 15 (my language with inserted other $|26-67| 46.33|6.67|$ 200

languages.

Table 2 Conclusion and Suggestion

All the lecturers switching the code of language in the learning process, the data refer to more than 244 number of code switching occurrences and the guestionnaire shown 86.67Y6 responded that they often did code switching when teaching in the class. From that finding it can be concluded that English has been affected by their language intentionally or unintentionally, The code switching occurred when the lecture changed the topic and situation in the learning process. According to the mode of analysis about the type of code switching, the data refer to 54 statements Of situational code-switching and nine statements of metaphorical code-switching, There are ten out of fifteen factors that lecturers agree the statements contained the factors cause the lecturers used code switching in the learning process. And the remaining five factors were classified disagree.

From this research, the writer hopes the phenomena of code switching in the level university could be increasing in the learning process. The way of the lecturers delivered their material is nice for students for learning many vocabularies. Apparently, it would building their skills in speaking English. Moreover, this finding might as reference for the lecturer to find a new strategy of learning using code-switching, this research could be a reference for the university to insert in their curriculum, for instance, in the end of teaching (five or ten minutes), lecturer and students have obligate to discuss a topic using English.

\section{BIBILIOGRAPHY}

Ahmad, B. H. (2009). Teachers" code-switching in classroom instructions for low English proficient learner. English Language Teaching, Vol. 2, No.2, 49-55. 
Apriana, A. (2007). Code mixing and code switching in the language of classroom instructions. Universitas Negeri Malang.

Cakrawarti, D. A. (2011). Analysis of code switching and code mixing in the teenlit canting cantig by Dyan Nuranindya. Semarang Diponegoro University.

Emzir. (2008). Metodologi peneltian pendidikan: kuantitatif \& kualitatif. Rajawali Pers: PT Raja Grafindo Persada.

Fasold, R. (1984). The sociolinguistics of society: introduction to sociolinguistics volume 1. Britain: Basic Blackwell Ltd.

Gulzar, M. A. (2010). Code-switching: awareness about its utility in bilingual Classrooms. Bulletin of Education and Research, Vol. 32, No. 2: pp. 23-44.

Inesta, E. R. (2006). Human behavior as language: some thoughts on Wittgenstein. Behavior and Philosophy, 34, 109-121.

Karimah, U. (2011). English code switching and code mixing found in advertisements of Kompas in the first week of July edition 2011. Universitas Muria Kudus.

Lewis, M. P. (2009). Ethnologue: languages of the world sixteenth edition. SIL International Online version. Retrieved March, 282013 from http://archive.ethnologue.com/16/ print.asp.

Meyerhoff, M. (2006). Introducing sociolinguistics. Routledge: Taylor \& Francis e-Library.

Montrul, S. A. Incomplete acguisition in bilingualism: Re-examining the age factor. John Benjamins Publishing Company.

Musyahda, L. (2002). Becoming bilingual: A view towards communicative competence. TEFLIN Journal, 13(1): 12-21.

Potowski, K., Rothman, J. (2011). Bilingual youth, Spanish in English-speaking societies. John Benjamins Publishing Company. 
Pradieta, F. (2007). The types and functions of lecturers" code switching in three branches of study of the English Department. Bina Nusantara University.

Sinulingga, E. K. (2009). Code switching and code mixing in "smart business talk" of Smart Radio 101.8 FM in the theme "how to become a superstar sales person". University of Sumatera Utara.

Strauss, A., \& Corbin, J. (1990). Basic gualitative research grounded theory: grounded theory procedures and technigues. New Burry Park: Sage Publications.

Wardaugh, R. (2006). An introduction to sociolinguistics fifth edition. Blackwell Publishing Ltd.

Wardaugh, R. (2010). An introduction to sociolinguistics. Malden, MA: Wiley Blackwell. 